\author{
Проф. др ЖАРКО ПЕТКОВИЋ \\ Универзитет у Београду \\ Филозофски факултет, Одељење историје \\ Чика Љубина 18-20, Београд, Србија \\ Е-aдpeca: zarkopetković@gmail.com
}

\title{
МАРКО АНТОНИЈЕ КАО НОВИ ДИОНИС
}

САЖЕТАК: У тексту се расправља о прагматичној мотивацији Марка Антонија да склопи савез са египатском краљицом Клеопатром, као и о политичким разлозима његовог представљања као Диониса у источним деловима Римске државе (од 41. године пре Христа). Антоније је желео да поведе рат против Парћана, али и да уједини хеленистички и римски свет - као Дионис. Притом, Антонијеви планови око Клеопатре и око рата против Парћана сусрећу се с његовом намером да се представи као Цезаров политички наследник (I, II). Цицероново и Плинијево сведочанство о Антонијевом појављивању у Риму у лављој запрези након Грађанског рата, знатно пре његовог одласка на Исток, јесте потврда да је он своју диониску инкарнацију доживљавао независно од планова за рат против Парћана и свог односа са Клеопатром/Изидом. Наиме, наступајући као Нови Дионис 49. године и непосредно после битке код Фарсале, Марко Антоније имао је у виду политичку поруку: Либер је био бог који је био близак плебсу и тако је асоцирао на сопствену анти-сенаторску, цезаровску, популарску политику (III, IV).

КљУЧНЕ РЕЧИ: Римска република, Марко Антоније, Цицерон, Плиније Старији, Плутарх, Дионис/Либер, лавља запрега, Клеопатра VII

После римског пораза у бици код Каре ${ }^{1}$ оновремено „источно питање” захтевало је нови расплет, с обзиром на то да војничка катастрофа коју је

${ }^{1}$ Извори: Т. S. R. Broughton, The Magistrates of the Roman Republic, II, New York 1952, 230; cf. B.A. Marshall, Crassus. A Political Biography, Amsterdam 1976, 157-161; T. P. Wiseman, "Caesar, Pompey and Rome", y: Cambridge Ancient History (CAH) IX², 1994, 402-403. - У тексту 
Рим претрпео под Красовом командом није била израз стварног стања снага између Парћана и Римљана. Римљани су имали разлога да верују да је победом осокољена Партска држава била стална претња њиховој власти над клијентским краљевима и да је, коначно, угрожавала провинције и читав римски поредак на Истоку. Тако узев, рат против Парћана није био само прилика да се увећа лични престиж Јулија Цезара или неког другог заповедника, него и прилика да се оствари један важан, неопходан империјални задатак. Цезар је планирао поход, ${ }^{2}$ али је страдао свега неколико дана пре него што се запутио према Истоку. Рат са Парћанима остао је дужност и обавеза тријумвира.

Након склапања Тријумвирата и победе над „ослободиоцима", ${ }^{3}$ после спроведених проскрипција и поделе сфера утицаја у Римској империји, пред Марком Антонијем отвориле су се нове могућности за државничко деловање и указало се ново поље за остваривање војничких успеха. У источним деловима Римске империје, који су по договору прешли под његову контролу, Антоније је успостављао нови поредак, онакав какав је он сматрао потребним. Тај поредак заснивао се на подршци клијентским владарима, ${ }^{4}$ a по неким решењима доста се разликовао од Помпејевог уређења Истока. ${ }^{5}$

Но, власт над источним провинцијама римске државе и контрола над клијентским краљевствима нису исцрпљивале амбиције Марка Антонија. Планирајући рат против Парћана, једине државе на Истоку, дакле изван римске, па и у доброј мери изван хеленистичке екумене, Антоније је желео, пре свега, да оствари политичку победу над Октавијаном, „дечаком”6 који је контролисао западне провинције. Победа над Парћанима требало је да Марку Антонију обезбеди онај ауторитет у војсци и држави који је Цезар стекао након освајања Галије. Наиме, Антонијеве заслуге у бици код Филипа остварене су у бици против сународника у Грађанском рату, ${ }^{7}$ а не против непријатеља римске државе и народа.

Да би повео велики рат на Истоку, Антоније је морао брижљиво планирати како ће учврстити римску власт, сакупити довољно новца, ${ }^{8}$ обезбе-

напомена коришћене су уобичајене скраћенице назива античких дела (према препоруци из четвртог издања The Oxford Classical Dictionary) и модерних публикација (по начину цитирања из L'annee Philologique). - Сва датовања у овом тексту дата су према претхришћанској ери.

${ }^{2}$ E.g. Dio, 43.51.1-2; 44.1.1; Cic. Att. 13.27.1 (=298.1 SB); Plut. Caes. 58.6; Suet. Caes. 44.3. Cf. Chr. Pelling, Plutarch, Caesar. Translated with an Introduction and Commentary, Oxford 2011, 436-438; J. Malitz, “Caesars Partherkrieg”, Historia 33 (1984), 21-59.

${ }^{3}$ Како је републиканце називао Цицерон: е.g. Phil. 2.31; Att. 14.12.2 (= 366.2 SB).

${ }^{4}$ App. BCiv. 5.75; Plut. Ant. 36.3-4; Dio, 49.32.1-5. Cf. H. Buchheim, Die Orientpolitik des Triumvirn M. Antonius, Heidelberg 1960, 49-52; 66-67.

5 Помпејев поредак на Истоку: Éd. Will, Histoire Politique du monde hellénistique (323-30 av. J.-C.), II ${ }^{2}$, Nancy 1982, 515-517; A.N. Sherwin-White, "Lucullus, Pompey and the East", y: CAH $\mathrm{IX}^{2}, 1994,265-270$. О једној важној разлици између Помпејеве и Антонијеве империјалне политике у Малој Азији: Аpp. 5.75.

${ }^{6}$ Cic. Phil. 13.24. Cf. e.g. Cic. Att. 14.12.2 (= 366.2 SB); 16.15 .3 (=426.3 SB); Fam. 12.23.2. Касније, реч puer је правилно схваћена као увреда, па је декретом Сената било забрањено да се тако говори о Октавијану: Serv. ad Verg. Ecl. 1.42.

${ }^{7}$ Chr. Pelling, "The Triumviral Period", y: CAH IX², 1994, 8.

8 App. BCiv. 5.4-7; Plut. Ant. 24; Jos. Ant. Jud. 14.12.2; Dio, 48.24.1; cf. D. Magie, Roman Rule in Asia Minor, I, Princeton 1950, 427-428. 
дити провијант и залеђину, мотивисати војнике. У те Антонијеве планове биће уткано савезништво (касније и брак или нека врста брака) са Клеопатром, ћерком Птолемеја XII, која је после династичких сукоба успела да постане краљица Египта. ${ }^{9}$ У складу са римском империјалном техником, Клеопатра је као клијентски владар добила знатна територијална проширења. ${ }^{10}$ Тај штедри Антонијев однос не треба, верујемо, тумачити као израз његове заљубљености која му је помутила разум и одвела га у националну издају. Таква тумачења карактеристична су за песнике Августове епохе и уопште за писце који су били под утицајем Августове пропаганде. Антоније је свој интерес у савезништву са Клеопатром могао наћи у томе што је она поседовала веома богату ризницу, ${ }_{11}^{11}$ неопходну за остваривање његовог плана о рату против Парћана. С друге стране, савезништво са Антонијем било је сасвим у складу са Клеопатрином дугогодишњом жељом да обезбеди своју позицију у Риму. ${ }^{12}$

На почетку свог пута на Исток Марко Антоније се 41. године пре Христа обрео у Ефесу, граду који је важио за caput Asiae. Ту се приказао као Дионис (Нови или Млади Дионис), „Доносилац радости” и „Доброделатељ”, а дочекивале су га жене, као Баханткиње, и мушкарци, као Силени и Панови. ${ }^{13}$ Ефешка епифанија Марка Антонија била је веома слична оној доцнијој из Атине 39. године: ${ }^{14}$ И познати Антонијев александријски „тријумф” из јесени 34. године личио је заправо на диониски опход. ${ }^{15}$

\author{
${ }^{9}$ Will Histoire Politique, $\mathrm{II}^{2}$, 527-539. \\ ${ }^{10}$ W. Ameling, s.v. "Kleopatra VII", DNP 6, 1999, col. 592; S. Burstein, The Reign of Cleo-
} patra, London 2004, 26; G. Hölbl, A History of Ptolemaic Egypt, London - New York 2001, 242. Ипак, када је Клеопатра тражила још територије на рачун Ирода, Антоније је одбио њене молбе: Joseph. Ant. Iud. 15.75-77; 79; 88; 91-92; 131; cf. R. Syme, The Roman Revolution, Oxford 1939, 260-261.

${ }_{11}$ Клеопатра је била толико богата да је у I веку после Христа владало уверење да је она саставила текст о претварању камена у злато: F. S. Taylor, "A survey of Greek alchemy", JRS 50(1930), 116.

12 Will, Histoire Politique, II², 527-537; Hölbl, History of Ptolemaic Egypt, 231-239.

13 Plut. Ant. 24.3-4; cf. A. Bruhl, Liber Pater, Paris 1953, 127. Нема разлога за скепсу (коју износи Chr. Pelling (ed.), Plutarch, Life of Antony, Cambridge 1988, 178) да је Антоније у Ефесу 41. године био поздрављен као бог, с обзиром на традицију обожавања владара као богова управо у том граду (Cic. Flacc. 60, што и са̂м Пелинг бележи), као и у другим градовима провинције Азије.

14 Plut. Ant. 60.3; Sen. Suas. 1.6; Сенека спомиње присуство мушкараца, жена и деце (cf. e.g. Eur. Bacch. 206-209 и SCU de Bacchanalibus, CIL I² 581, 19-21) приликом Дионисовог/ Антонијевог уласка у Атину, што сведочи да је дочек имао култни карактер; у питању је морао бити Өíaбоร. Поред тога, по Сенеки: „Антоније је имитирао Либера (Диониса) у обла-

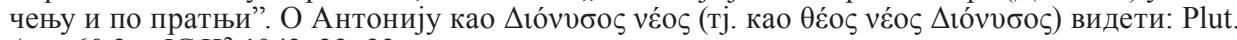
Ant. 60.3 и $I G \mathrm{II}^{2} 1043,22-23$.

15 Plut. Ant. 50.6; Dio Cass. 49.40; Vell. 2.82.4; cf. Hölbl, A History of Ptolemaic Egypt, 234-235. Порекло тријумфа Римљани су везивали, између осталог, са Дионисовим епитетом

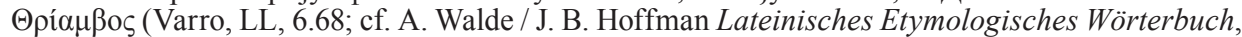
II $^{3}$ Heidelberg 1938, 707-708; W. Ehlers, s.v. Triumphus, RE 7A(1938), coll. 493-494; M. Beard, Roman Triumph, Cambridge, Mass. / London 2007, 245), тако да римски тријумф садржи низ 
Дионис је бог којег су људи, по паганском схватању, могли да виде управо у оваквим приликама, дакле приликом свечаних поворки унутар градских зидина. ${ }^{16}$ Опис Антонијевог диониског опхода који доноси Сократ са Родо$\mathrm{ca}^{17}$ садржи детаље који су, иако компромитујући за Антонија, типични за наступ самоувереног човека - као реинкарнације Диониса - раскалашног понашања, па, рекло би се, и недопустивог за римског императора. Дион Касије каже да је самог себе назвао Новим Дионисом и да је тражио од других да га тако зову, а и Велеј Патеркул бележи да је у Александрији Антоније наредио да се назива Новим Либером. ${ }^{18}$ Уз ова сведочанства из текстова о Антонију као Дионису, требало би додати и нумизматичка: на новцу који је ковао на Истоку, Антоније се приказује као Дионис, односно Нови Дионис. ${ }^{19}$

Дионис је у свом индијском походу покорио читаву Азију, а у историјско доба Александар Велики је поновио његов подвиг. ${ }^{20}$ Међу династијама које су наследиле Александрову империју Лагиди су били нарочито везани за Диониса - трудили су се да своје порекло успоставе од овог бога. ${ }^{21}$ Птолемеј Филаделф се позивао на Дионисов индијски поход представљајући се као легитимни Александров наследник. ${ }^{22}$ Но, суштина Дионисовог божанског прегнућа тек је уследила: после азијског похода, Дионис је ујединио Исток и Запад. ${ }^{23}$ Дакле, Марко Антоније је претендовао да се његова диониска инкарнација протумачи на овај начин. Антонијева диониска појава јесте знак о вишој империјалној амбицији - да уједини римску-хеленистичку државу под својом влашћу, а не само о плановима за један велики источни поход. Планирана победа на Истоку утирала је пут његовим амбицијама на Западу, морао је тако мислити неповерљиви Октавијан.

диониских асоцијација (H. Versnel, Triumphus, Leiden 1970, 20-38; 288-299), с чим је сигур-

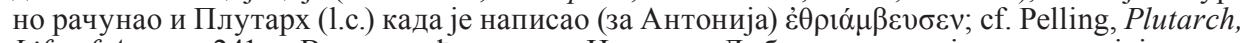
Life of Antony, 241. - Веза између рата на Истоку и Либера опстала је и у каснијој епоси: поводом похода Августовог унука на Исток, Овидије (Ars 1.189-90) пева: Nunc quoque qui puer es, quantus turn, Bacche, fuisti cum timuit thyrsos India victa.

${ }^{16}$ W. F. Otto, Dionysus. Myth and Cult, London 1965. (превод немачког издања из 1933. године), 82-83; R. Seaford, Dionysos, London - New York 2006, 47.

${ }_{17}$ Athen. $4.148 \mathrm{c}-\mathrm{d}=$ FGH 192, f. 2; cf. Bruhl, Liber Pater, 305.

18 Vell. 2.82.4; Dio, 48.39.2.

${ }^{19}$ D. Mannsperger, "Apollo gegen Dionysos. Numismatische Beiträge zu Octavian Rolle als Vindex Libertatis", Gymnaisum N.F. 80 (1973), 384-390; Bruhl, Liber Pater, 127-128; cf. M.H. Crawford, Roman Republican Coinage, II, Cambridge 1974, 743, нап. 4.

20 Arr. An. 5.1.1-2.1. Strabo, 15.1.6-8; Plut. Alex. 58.6; 67.1. Cf. F.A. Voigt, s.v. "Dionysos, Indischer Feldzug" y: Ausführiliches Lexikon der Griechischen und Römischen Mythologie (hrsg. W. H. Roscher), I, Leipzig 1884, coll. 1087-1089; F. Schahermeyer, Alexander der Grosse. Das Problem seiner Persönlichkeit und seines Wirkens, Wien 1973, 410-413; H. Berve, Das Alexanderreich auf prosopographischer Grundlage, I, München 1926, 94; P. Goukowsky, Essai sur les origines du mythe d'Alexandre (336-227 av. J.-C.), II, Nancy 1981, 79-83; J. R. Hamilton, Plutarch. Alexander. A Commentary, Oxford 1969, 174, 185.

21 За порекло Лагида од Диониса и Херакла види: OGIS I, 54, 4-5, Satyrus FHG 3, p. 165.

22 Видети нпр. Каликсенов опис великог Дионисовог повратка из Индије који је приредио Птолемеј Филаделф, приказујући се тако као Александров легитимни наследник: Athen. 5.200c-200b. Cf. C. Schneider, Kulturgeschichte des Hellenismus, I, München 1967, 510 511; A. D. Nock, "Notes on the Ruler-Cult, I-IV", JHS 18(1928), 26, n. 22; Hölbl, A History of Ptolemaic Egypt, 39-40; Beard, Roman Triumph, 315-316.

${ }^{23}$ Schahermeyer, Alexander der Grosse, 410. 
Међутим, пре тога рата, до кога стицајем околности никада није ни дошло у тако величанственом есхатолошком облику, Антоније - Нови Дионис - сусрео се у Тарсу на реци Кидно са Клеопатром - прикладно обученом као Афродита, односно Изида. ${ }^{24}$ Тако је сусрет Антонија и Клеопатре освештан, али не само тај сусрет него и савез, заједничка владавина над Истоком. ${ }^{25}$ Плутарховско-шекспировски опис тог грандиозног сусрета, прескупог, за Антонија очаравајућег и недостижног у својој префињености, не укида, међутим, други, основни, политички смисао, који се 41. године помаљао иза чувене речне параде на Кидну. Наиме, један римски генерал, преобучен у Диониса, освајача Истока и доноситеља слободе, у савезу са хеленистичком краљицом Изидом, која влада баснословним богатством Египта, планирао је велики поход против Парћанима, источњачких варвара који су се супротстављали уједињеној грчко-римској цивилизацији, како би тако успоставили своју власт над екуменом.

Тадашње амбиције египатске краљице нису биле велике: желела је само да се пред победником оправда јер су се појавиле гласине да је подржавала Касија у недавно завршеном Грађанском рату. ${ }^{26}$ Антоније је поступао сасвим прагматично. Иако је Ирод (касније Велики) био суочен са различитим оптужбама, између осталог да је био на Касијевој страни, Антоније га је ипак подржао и именовао за тетрарха, а нешто касније, 40. године, уз Октавијанов и Антонијев пристанак, Сенат га је признао за краља Јудеје. ${ }^{27}$ Антоније је тако и с Клеопатром ускладио интересе. ${ }^{28}$ Помогао јој је у стандардним лагидским династичким преокупацијама: да се осуди њена сестра Арсиноја, као и претходни управник Кипра Серапион. ${ }^{29}$ Било би сасвим погрешно помислити да је Антоније само испуњавао Клеопатрине жеље; Серапион је, на пример, египатску флоту својевремено предао Бруту и Касију, ${ }^{30}$ па је казна била очекивана.

${ }^{24}$ Plut. Ant. 26-28.1; App. BCiv. 5.8-10; Dio, 48.24.2; Joseph. Ant. Iud. 4.13.1; cf. Bruhl Liber Pater, 127-128; H. Bengston, Antonius. Triumvir und Herrsher der Orients, München 1977, 162-163; Will Histoire Politique, II ${ }^{2}, 540$; E. Goltz Huzar, Mark Antony. A Biography, Minneapolis 1978, 153-154; Pelling, Plutarch, Life of Antony, 189-192.

${ }^{25}$ Када C. Friesen, Reading Dionysus. Euripides Bacchae and the Cultural Contestations of Greek, Jews, Romans and Christians, Tübingen 2015, 98, пише да је „тадашње Антонијево присвајање имена Новог Диониса који се развио из његовог односа са Клеопатром”, она не узима у обзир Цицероново шаљиво интонирано упозорење Атику - из 49. године [Cic. Att. 10.13.1 (= 205.1 SB)] - да се чува Антонијевих лавова, као и Плинијево сведочанство да је Антоније био први који је увео, после битке код Фарсале, лавовску запрегу у Рим. Иако се ове животиње могу везати како за Диониса тако и за Херакла (cf. Pelling, Plutarch, Life of Antony, 139), мислимо да има довољно разлога да се ови лавови протумаче као Дионисови пратиоци (видети сл., III).

26 Plut. Ant. 25.1; заправо, један египатски заповедник предао је, против Клеопатрине воље, помоћ (видети текст уз нап. 30) „ослободиоцима” (cf. Pelling, Plutarch, Life of Antony, 184).

${ }^{27}$ Joseph. Ant. Iud. 14.12.2; 13.1; 14.1-5; Bell. Iud. 1.12.4-5; 14.1-4; cf. E. Schürer, The History of the Jewish People in the Age of Jesus Christ (175 B.C. - A.D. 135), rev. and ed. by G. Vermes, F. Millar, M. Goodman, I, Edinburgh 1973, 278, 281.

${ }_{28}$ Plut. Ant. 26; Athen. 4.147; App. 5.9; Dio, 48.24; Joseph. Ant. Iud. 15.4.1.

29 App. 5.9; Dio, 48.24.3; cf. W. Drumman / P. Groebe, Geschichte Roms in seinem Übergange von der republikanischen zur monarchischen Verfassung oder Pompeius, Caesar, Cicero und ihre Zeitgenossen, $\mathrm{I}^{2}$, Berlin 1899, 286, који, међутим, управо као и антички писци, превише наглашавају емотивну мотивацију Марка Антонија.

30 Pelling “The Triumviral Period”, 12; Fr. Münzer, RE IA(1914) s.v. Sarapio, col. 2394. 
Убрзо је Антоније напустио Азију и, обавивши важне послове у Сирији, 31 на Клеопатрин позив допутовао у Александрију као privatus. Њих двоје су постали љубавници. ${ }^{32}$ Антонијева диониска инкарнација била је и прикладна и усклађена са владарским идентификацијама египатских лагидских владара, ${ }^{33}$ док је Клеопатра и даље, природно, фигурирала као Нова Изида, Дионисова пратитељка. ${ }^{34}$ Но, за римска схватања то је била права infamis amor која је - у свом исходу - одвела у смрт толике римске војнике код Акција и осрамотила Марка Антонија. ${ }^{35}$ Међутим, десет година раније, ако је и желео да предвиђа будућност, он сигурно није помислио на покољ својих војника, ни на сопствени (привремени) кукавичлук. Освојивши Клеопатру, Антоније се могао представити као Цезаров наследник, поготову ако би се Цезарова величина - антонијевски инфантилно - доводила у везу са његовим љубавним подвигом. Или, нешто другачије речено, Антоније је мислио да га Цезарова краљевска љубавница, баш као и његово првосвештенство у култу божанског Јулија, ${ }^{36}$ легитимизира за Цезаровог политичког наследника. Дакле, избија у први план анти-октавијановски смисао Антонијевог односа са Клеопатром.

У том смислу, једва да је чудно да је касније, један Августу близак песник, доживљавао Антонијеву и Клеопатрину љубав као срамотну. ${ }^{37}$ Та оцена изречена је много година касније, после Октавијанове победе код Акција, када су сви исходи били познати и када је Дионис напустио Александрију. ${ }^{38}$ Но, стихови у којима се оплакивала пропаст римске војничке и мушке врлине не само да нису постојали приликом сусрета Марка Антонија и Клеопатре, него Антонију није ни било важно што је таква интерпретација односа са египатском краљицом била могућа. Ту несмотреност искористио је његов ривал.

Независно од Октавијанове пропаганде, и остајући при упоређивању Антонија са Цезаром, може се рећи да није било појмљиво да ће се Цезар

31 App. BCiv. 5.7; Dio, 48.24.3; Liv. Epit. 127.

32 App. BCiv. 5.11; Dio, 48.24.2; Plut. Ant. 28-29.

33 Везаност Лагида за Диониса није била ограничена само на Птолемеја Филаделфа. Лагиди су сматрали да потичу, по женској линији, од Диониса (OGIS I, 54.4-5). О блискости Птолемеја Сотера са Дионисом видети: Н. Kyrieleis, Bildnisse der Ptolemäer, Berlin 1975, 7-8. Култ Диониса доживео је прави процват у време Птолемеја Филопатора (cf. Hölbl, A History

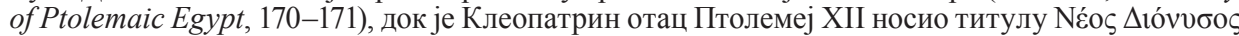
(стела ВM 1026 (886); SEG VIII, 468; cf. E.A.E. Reymond, From the records of the priestly family from Memphis, Wiesbaden 1981, 150-164), чиме се и Антоније китио (видети горе, напомене 19 и 24).

${ }^{34}$ E.g. Plut. Ant. 54.9; 60.5; Serv. ad Aen. 8.696; Dio, 50.5.3; 50.25.3-4; cf. F. Dunand, Le culte d'Isis dans le bassin oriental de la Méditerranée, II, Leiden 1973, 21; cf. Hölbl, A History of Ptolemaic Egypt, 289-292; Will Histoire Politique, II2, 539; D. Plantzos, "The Iconography of Assimilation: Isis and Royal Imagery on Ptolemaic Seal Impressions", in: I. Panagiotis, A. S. Chankowski, C. Lorber (edd.), More Than Men, Less Than Gods: On Royal Cult and Imperial Worship. Proceedings of the International Colloquium Organized by the Belgian School at Athens (November 1-2, 2007), Leuven 2008, 389-396.

35 Prop. 2.16.37-40.

${ }^{36}$ Cic. Phil. 2.110; Cf. J. Rüpke, Fasti sacerdotum. Die Mitglieder der Priesterschaften und das sakrale Funtionspersonal römischer, griechischer und jüdisch-christlicher Kulte in der Stadt Rom von 300 v. Chr. bis 499 n. Chr. Teil. 2: Biographien, Wiesbaden 2005, 770-771, no. 669.

37 Prop. 2.8; 2.16.37-42; 3.11 .

38 Plut. Ant. 75.4-5; cf. Pelling, Plutarch, Life of Antony, 303-305; P. Zanker, The Power of Images in the Age of Augustus (transl. A. Shapiro), Ann Arbor 1988, 47. 
одати сумњивим забавама, да ће се облачити у робовско одело, ${ }^{39}$ да ће изгледати као демаскулирани поданик једне оријенталне - демонизоване - краљице, уопште да ће учинити да Рим умало доживи судбину своје постојбине Илиона, који је претворен у прашину због исквареног, штеточинског судије и једне жене, странкиње притом. ${ }^{40}$ Цезар је, што за Проперција и Антонија није било достижно, био под пуном контролом свог односа са женама.

У основи, Антоније није импресионирао традиционалистички Рим: он је у оријентално-деспотском маниру наследио љубавницу свог претходника, свог императора, што је било тако удаљено од прокламованих републиканских начела. За неко време, Антоније је могао бити спокојан јер је јавно екстравагантно понашање римских императора више згражавало моралистички настројене непријатеље - оне преживеле после пораза Републике - него што је заиста могло да угрози његов положај. Антоније је био војник и могао је с презиром да гледа на „пропаганде” победе његових непријатеља, очекујући да ће, када их победи у рату, све њих ућуткати, можда са подједнаком суровошћу како је поступио са Цицероном крајем 43. године.

Наредно питање које би се могло поставити јесте да ли је Антоније решио да се представи као Дионис/Озирис тек када је своју политику усмерио према Истоку и, притом, видео прилику да Клеопатру/Изиду веже за своје планове. Одговор на ово питање зависи од анализе Цицероновог сведочанства (из маја 49. године) о Антонијевим лавовским кочијама, ${ }^{41}$ што би се могло односити, како истраживачи оцењују, како на Дионисове, тако и на Хераклове лавове. ${ }^{42}$ (Познато је да су Антонији тврдили да вуку порекло од Антона, Херакловог сина. ${ }^{43}$ ) Поменута Цицеронова реченица јаснија је захваљујући Плинијевом сведочанству да је Марко Антоније први Римљанин

\section{Plut. Ant. 29.2.}

40 Prop. 3.3.18-20. Париса је лако идентификовати са Марком Антонијем; обојица су из боја побегли у загрљај жени: Plut. Comp. Ant. et Dem. 3.4; cf. J. Griffin, "Propertius and Antony", JRS 67 (1977), 19.

${ }^{41}$ Cic. Att. 10.13.1 = 205.1 SB: tu Antoni leones pertimescas cave. - Упркос томе што ce у неким издањима Цицеронове Друїе Филийике 58 спомињу „лавље кочије” (Cicero, Second Phillippic Oration, ed. W.K. Lacey, Warminster 1986), уверени смо да је једино исправно читање овог места sequebatur raeda cum lenonibus („,Пратила су га кола са курвама”), како су многи издавачи усвајали (е.g. W.C.A Kerr u старој The Loeb Classical Library), а што је - имајући у виду рукописну традицију (Cod. Harleianus 2682) - усвојено у постумној редакцији Шеклтон Бејлија (Cicero XVa, Philippics 1-6, ed. Shackleton Bayley, revised by J.T. Ramsey and G. Manuwald, Cambridge, Mass. / London 2009), као и у његовом ранијем издању Филийика (Cicero, Philippics, Chapel Hill / London 1986); cf. Cicero, Philippics I-II, ed. J. T. Ramsey, Cambridge 2003,246 . Стога се у тексту позивамо само на неоспорни текст из Писама Айику - да je y Phil. 2.58 стајало, као што верујемо да није, sequebatur raeda cum leonibus, то би само потврђивало оно што знамо из Цицероновог савременог писма.

42 Хераклови: Drumman / Groebe, Geshichte Roms, 43; Хераклови или Дионисови: Pelling, Plutarch, Life of Antony, 139; B. Krostenko, Cicero, Catullus and the Language of Social Performance, Chicago / London 2001, 294.

43 Plut. Ant. 4.1-2; App. 3.16; 19; Crawford Roman Republican Coinage, II, I, 502, no. 494 2a-b; cf. Pelling, Plutarch, Life of Antony, 24. 
који је ујармио лавове и у таквој запрези прошао Римом. Десило се то, изричит je Плиније, у данима после битке код Фарсале, ${ }^{44}$ дакле неколико година пре него што се запутио на Исток. И Плутарх сведочи о Антонијевом раскалашном понашању у тим данима, о парадирању са колима, проституткама, љубавницом Китеридом, што је укључивало и лавове упрегнуте у кочије. ${ }^{45}$ Лав је био посебно значајан за Антонија: током 43/42. и 38. године ковао је новац са тим мотивом. ${ }^{46}$

Но, чини се да је могуће одговорити на питање о култном смислу Антонијевих лављих процесија ако се у ширем контексту анализирају Плинијеве и Цицеронове речи. Почнимо од савременика догађаја, Цицерона. Писма која је упућивао Атику током 49. године тицала су се пре свега - када говоримо о њиховом политичком слоју - питањем повлачења оптимата и Помпеја из Рима, панике која је настала када се та вест проширила. ${ }^{47}$ Цицерон је писао о запоседнутом Риму, о свом незадовољству Помпејевим начином вођења рата. ${ }^{48}$ Притом, Цицерон се повукао са Помпејем и био забринут за Атика, који је ипак остао у Риму, излажући се ризику. (У мају месецу Цезарова clementia још увек није морала бити опште позната или прихваћена као његова тековина; његови непријатељи имали су разлога да верују да би он могао поступити сасвим другачије, нпр. као Сула када је са војском ушао у Рим током претходног грађанског рата). Стога, када Цицерон полази од тога да је Атик уплашен, то се јамачно односи на основно питање безбедности једног од присталица оптимата, ${ }^{49}$ Помпејевог пријатеља ${ }^{50}$ који је остао у Риму у часу уласка непријатељске војске.

Да би Атиков страх од Антонијевих лавова могао бити реалан, потребно је замислити да су то лавови Диониса, ${ }^{51}$ једног бога блиског плебсу, 52 Управо је популарску политику присвојио Цезар. С друге стране, чини се

44 Plin. NH 8.55: Iugo subdidit eos (leones) primusque Romae ad currum iunxit M. Antonius, etu quidem civili bello cum dimicatum esset in Pharsaliis campis, non sine ostento quodam temporum, generosos spiritus iugum subire illo prodigio significante.

45 Plut. Ant. 9.2; ово сведочанство јесте инвективно интонирано, што наводи на помисао да се Плутарх користио Цицеронове Филийике (Pelling, Plutarch, Life of Antony, 139). С обзиром на неоспорну негативну интонацију Антонијевог понашања (током 47. године /?/ како следи из 9.1), овај одељак неће бити посебно анализиран јер не може понудити поуздано сведочанство о диониском или уопште култном смислу Антонијеве процесије. Ипак, вреди поновити да и на овом месту Плутарх потврђује датовање Антонијеве параде са лавовима пре његовог одласка на Исток.

46 Crawford (нап. 19), I, 499, по. 489/5-6 и I, 534, no. 533/1.

47 Cf. Cic. Att. 7.10 (133 SB; 18. јануар 49); 7.11 (134 SB; 21.(?) јануар 49), па све до Цицероновог писма из маја (Att. $10.13=205 \mathrm{SB})$, о коме се овде ради.

48 Cic. Att. 8.7 (=155.7 SB) (21. фебруар 49).

${ }^{49}$ Cic. Leg. 3.37: Атик: „никада ми се није допала ни једна популарска мера” ... „мислим да је најбоље уређење ... оно која даје власт оптиматима”.

${ }_{50}$ Cic. Att. 8.7.2 (= 155.2 SB); Nepos, Att. 7.2. Још раније, 58. године, Атик је био у прилици да се код Помпеја залаже за Цицеронов повратак из прогонства: Cic. Att. 3.8.3 (= 53.3 $\mathrm{SB}) ;$ 3.9.2. (= 54.2 SB).

${ }^{51}$ Cf. e.g. D. Costa, "Dionysos enfant, les bacchoi et les lions", RA, 6e série, 39/2 (1952), 170-179.

52 Ранорепубликански култ Либера, Либере и Церере на Авентину је недвосмислено плебејски обојен: M. Beard, J. North, S. Price, Religions of Rome, I, Cambridge 1998, 64-66; G. Wissowa, Religion und Kultus der Römer, München 1902, 245; Bruhl, Liber Pater, 30-45; F. Prayon, s.v. Liber, Liberalia, DNP 7 (1999), 136. 
као сасвим невероватно да би се Антоније током 49. и 48. године - без обзира на своје прокламовано породично порекло - поигравао јавно са ликом Херакла, бога који је био везан за Цезаровог противника Помпеја, ${ }^{53}$ или за Сулу, ${ }^{54}$ главног популарског непријатеља. Поготову то није вероватно јер је Плиније датовао Антонијев перформанс са лавовима после битке код Фарсале, у којој је лозинка Помпејевих војника била Hercules invictus. 55

Мислимо да ће овакву интерпретацију Цицеронових речи подржати анализа Плинијевог сведочанства. Наиме, поред цитиране реченице, ${ }^{56}$ Плиније додаје да је на кочији коју су вукли лавови поред Антонија седела и његова тадашња љубавница, mima Китерида. ${ }^{57} \mathrm{C}$ обзиром на то да се Антоније, у својој киликијској диониској паради, појављивао са Клеопатром као Изидом (Афродитом), пратитељком Диониса, ${ }^{58}$ природно би било претпоставити да је ту улогу морала имати и Китерида, разуме се у једном нижем формату, баш како је и Антонијев положај 49. или 48. био неупоредиво мање значајан него онај из 41. године.

Како нема иконографских или наративних сведочанстава да се Херакле појављује у овом контексту (лавови, кочија) у женском друштву, морало би се закључити да се и Плинијева реченица заправо односи на Антонија као инкарнацију Диониса, и то из периода пре него што би га његове амбиције да се на Истоку представи као владар могле нагнати да се идентификује са овим богом. 59

Цицеронова и Плинијева сведочанства о Антонијевој диониској инкарнацији независна су једна од других. Цицерон је заправо почетком 49. године изнео једну безмало ироничну примедбу о Марку Антонију као Дионису. Појављивање Марка Антонија (и његове љубавнице) на лављој запрези Плиније пак датује касније, после битке код Фарсале. ${ }^{60}$ За Плинијеву поуку о смислу те Антонијеве запреге - оставимо по страни наивност изнесеног објашњења - необично је важна хронологија, тако да Плиније и Цицерон очигледно не описују исти догађај који, грешком, различито датују. Дакле, било је (макар) две такве Антонијеве јавне процесије, ${ }^{61}$ што, верујемо, говори

53 F. Santangelo, "Pompey and Religion", Hermes 135/2(2007), 228-233; B. Rawson, "Pompey and Hercules", Antichthon 4(1970), 30-37.

54 A. Keaveney, Sulla and the Gods, in: C. Deroux (ed.), "Studies in Latin Literature and Roman History", Coll. Latomus 3, Brussels 1983, 44-47.

55 App. BCiv. 2.76.

56 Видети горе, напомена 44.

57 Plin. NH 8.55: Nam quod ita vectus est cum mima Cytheride. Слично, Plut. Ant. 9.2.

58 Видети горе, напомене 24 и 34.

59 Цицерон сведочи (Phil. 2.58) да је Антоније, приликом свог опхода око Италије (са Китеридом у колима) био овенчан ловором. Нема потребе да се ловор тумачи као дионисијевски символ (e.g. Philostr. Vita Ap. 2.6), пошто је он могао потицати из Антонијеве имитације римског тријумфа.

60 Plin. NH 8.55: ... quidem civili bello cum dimicatum esset in Pharsaliis campis, non sine ostento quodam temporum, generosos spiritus iugum subire illo prodigio significante. То је у складу (додуше, само донекле) са датовањем Антонијевих лављих запрега које следи из Plut. Ant. 9.1-2.

61 Заправо, вероватно је било више оваквих процесија, ако узмемо у обзир и Плутархово сведочанство из Ant. 9.2 које би се могло односити на 47. годину (види горе, текст уз нап. 44 и 45). Но, с обзиром на уску везу између овог Плутарховог одељка и Цицеронове инвективе (Phil. 2.58), држимо да не треба заснивати аргументацију на овим речима. 
о његовој чврстој жељи да се - пре него што је кренуо на Исток - прикаже у римском свету као Либер, што је касније у Азији интерпретирано као Нови Дионис.

\section{IV}

Уз поменуту „цезаровску” или „плебсовску” политичку мотивацију овакве параде не треба изгубити из вида да је јавно прослављање Диониса - Римљани би те прославе назвали Баханалијама - представљало недвосмислено антисенаторску манифестацију. Наиме, Марко Антоније је овим јавно прекршио стару забрану јавне прославе Баханалија у Италији, коју је донео римски Сенат још 183. године. ${ }^{62}$ Та забрана била је један од најснажнијих израза ауторитета Сената, донесена у време када је престиж Сената био на свом врхунцу. Јавно кршење такве забране, Дионисова парада улицама Рима, била је у складу са популарско-цезаровским политичким деловањем Марка Антонија, који је у тим годинама (49. и 48. године) био вероватно најважнији човек Цезаровог (личног) режима.

С тим антисенаторским и популарским капацитетом Диониса, рачунао je, пре Антонија, и Гај Јулије Цезар: Сервије, поводом Вергилијевих стихова у којима стоји да је Дафнис (дакле, Цезар) научио људе да упрежу јерменске тигрове, да их је научио да играју бакхичке игре, каже да је било опште познато да је баш он први који је увео култ оца Либера у Рим. ${ }^{63}$ Наравно, без обзира на изричитост исказа, Сервије сигурно није мислио дословно да је Цезар био први оснивач Либеровог култа у Риму; 64 пре се ради о томе да је он диониским прославама унео нови живот и, верујемо, удахнуо актуелну политичку поруку. Дакле, изгледа да је Марко Антоније, када се 49. и 48. године приказивао као Дионис, само спроводио једну Цезарову религиознополитичку манифестацију: Цезар је баш био први, следи из Вергилијевих стихова, који је упрегао дивље звери, Марко Антоније је то поновио. ${ }^{65}$

Постоји још један податак који би се могао протумачити као сведочанство Цезарове везаности за Диониса/Либера. Наиме, Цезар је почетак похода против Парћана планирао непосредно после прославе Либералија (18. марта), 66 дакле на дан који би се могао довести у везу са Дионисовим походом на Исток,

62 Liv. 39.8-19; 29.8-10; 40.19.9-10; ILS 18; cf. G. Wissowa, s.v. "Bacchanal”, RE 2(1896) coll. 2721-2722; Bruhl, Liber Pater, 86-116; R. Turcan, "Religion et poilitique dans l'affaire des Bacchanales", RHR181/1(1972) 3-28.

63 Serv. ad Verg. Ecl. 5.29; Verg. Ecl. 5.28-30; cf. Bruhl, Liber Pater, 124-127; R. Turcan, “César et Dionysos”, y: Hommage à la mémoire de J. Carcopino, Paris 1977, 315-325. - О идентификацији Цезара са Дафнисом (Дафнидом) видети: Т. Drew, "Virgil's Fifth Eclogue: A Deffence of the Julius Caesar-Daphnis Theory”, CQ 16/2(1922) 57-64; P. Grimal, "La « Ve Églogue » et le culte de César", in: Mélanges d'archéologie et d'histoire offerts à Charles Picard, I, Paris 1949,408 , док је сасвим редак скептицизам који износи W. Claussen (A Commentary on Virgil Eclogues, Oxford 1994, 152, нап. 4), притом и недовољно аргументован.

64 Cf. Seaford, Dionysos, 61.

65 Тигрови би могли бити само поетска варијација за лавове или замена јер се спомињу у претходном стиху.

66 App. BCiv. 2.114. 
мада, истина, у тај дан пада и његова победа код Мунде. ${ }^{67}$ Уколико би ипак остали при дионисијевском тумачењу смисла датума Цезаровог похода - битка код Мунде могла је управо са том намером бити вођена баш 18. марта - испоставља се да је Антоније, представљајући се као Дионис у Риму и на Истоку, заправо чинио оно што је најбоље умео. Он је као први човек цезаровске странке (после мартовских Ида 44. године), деловао на исти начин као што је то чинио његов велики генерал: грубо речено, Марко Антоније је имитирао Цезара.

На Цезарову везаност за Диониса сигурно је утицао Гај Марије, који је, након својих славних победа над Кимбрима и Тевтонцима, јавно пио, у диониском маниру, јер је тако чинио Либер после свог Индијског тријумфа, како каже један од писаца који о томе сведоче. ${ }^{68}$ Угледајући се на Цезара, Марко Антоније је заправо наставио традицију која вуче своје корене од утемељивача странке популара - „диониски тријумф” био је једна римска популарска манифестација, а не пука Антонијева екстраваганција, дрско шенлучење, како је то представљао Цицерон, његов архинепријатељ.

ORIGINAL SCIENTIFIC PAPER

\author{
Prof. Dr. ŽARKO PETKOVIĆ \\ University of Belgrade \\ Faculty of Philosophy, Department of History \\ Čika Ljubina 18-20, Belgrade, Serbia \\ E-mail: zarkopetković@gmail.com
}

\title{
MARK ANTONY AS A NEW DIONYSUS
}

SUMMARY: The Dionysian model as anti-senatorial, plebeian, popularis, and at its last political reading Caesarian, was woven into the political profile of Mark Antony and defined before he appeared in Ephesus in $41 \mathrm{BC}$ as a (New) Dionysus. Namely, it is beyond a reasonable doubt that the lion chariots (mentioned by Cicero, Pliny, and Plutarch in the descriptions of Antony's performance between 49 and $47 \mathrm{BC}($ ?)) were part of the performance of the Dionysian triumph. It does not seem likely that the chariots were part of Herculean iconography, as another possible explanation reads. Introducing himself as Liber in Italy, Mark Antony followed in the footsteps of other populares: C. Marius and Julius Caesar, which was of special importance for Antony. Julius Caesar used Liber - a friend of the Roman plebs, an egalitarian god, a liberator - to establish his position among the lower classes, the position which was represented as anti-senatorial. At a time when Mark Antony publicly appeared as Liber on the streets of frightened Rome, in the early 49 BC, his trip to the East, several years later, meeting and alliance with Cleopatra, and propaganda benefits from the Dionysian processions in Ephesus, Alexandria, and elsewhere were totally unpredictable. When new circumstances took him to the eastern Roman provinces, Antony was perceived as the heir of the Hellenistic ruling tradition, as a triumphant, victorious in the East but also a unifier of the East and West. So, Antony appeared to be the reincarnation of Dionysus.

KEYWORDS: Roman Republic, Mark Antony, Cicero, Pliny the Elder, Plutarch, Dionysus/Liber, lion chariots, Cleopatra VII

${ }^{67}$ Malitz, “Caesars Partherkrieg”, Historia 33(1984), 43, нап. 113, мисли да би победа код Мунде (cf. Bell. Hisp. 31.8) могла бити од значаја при Цезаровом избору датума поласка у рат против Парћана. Ипак, он као да нема у виду да се Либералије прослављају у овај дан.

68 Val. Max. 3.6.6. Cf. Front. Strat. 1.11.12; Plut. Mar. 17.2-5. 